\title{
PENGARUH BAHASA INDONESIA DAN BAHASA INGGRIS DI ERA GLOBALISASI
}

\section{Dafi Firmansyah}

Program Studi Pendidikan Bahasa Indonesia, Universitas Sebelas Maret

Email : dafifirmansyah@gmail.com

\begin{abstract}
Abstrak
Bahasa Melayu merupakan akar dari bahasa Indonesia. Ketika Belanda singgah di Indonesia, bahasa Melayu pun digunakan sebagai bahasa resmi kedua dalam korespondensi dengan orang lokal. Akhirnya, bahasa Melayu dan bahasa Belanda bersaing semakin ketat. Bahasa Inggris pertama kali digunakan pada awal abad pertengahan Inggris yang pada awalnya adalah bahasa Jerman bagian barat. Bahasa Inggris sekarang bukan lagi hal yang sangat tidak biasa, tapi bahasa Inggris telah menjadi norma terutama di era globalisasi. Mampu berbicara dengan baik dan lancar bahasa Inggris tidak lagi menjadi nilai tambah, namun sudah menjadi tuntutan atau kebutuhan bagi setiap orang di era globalisasi saat ini. Ini karena pengaruh bahasa Inggris di hampir semua aspek dalam kehidupan.
\end{abstract}

Kata kunci: Bahasa Indonesia, Bahasa Inggris, Ilmu pengetahuan, Peran Bahasa.

\begin{abstract}
Malay is the root of Indonesian. When the Dutch stopped in Indonesia, the Malay language was used as the second official language in correspondence with local people. Finally, Malay and Dutch languages competed increasingly tightly. English was first used in early medieval England which was originally western German. English is no longer a very unusual thing, but English has become the norm especially in the era of globalization. Being able to speak well and fluently in English is no longer an added value, but has become a demand or need for everyone in the current era of globalization. This is because of the influence of English in almost all aspects of life.
\end{abstract}

Keywords: Indonesian Language, English Language, Science, Language Role. 
PENDAHULUAN

Bahasa Melayu merupakan akar dari bahasa Indonesia. Ketika Belanda singgah di Indonesia, bahasa Melayu pun digunakan sebagai bahasa resmi kedua dalam korespondensi dengan orang lokal. Akhirnya, bahasa Melayu dan bahasa Belanda bersaing semakin ketat.

Walaupun Gubernur Jenderal Roshussen telah mengusulkan bahasa Melayu untuk menjadi bahasa pengantar di sekolah-sekolah rakyat, ada pihak-pihak yang gigih menolak bahasa Melayu di Indonesia. Van der Chijs, seorang berkebangsaan Belanda, menyarankan supaya sekolah memfasilitasi ajaran bahasa Belanda. JH Abendanon yang merupakan Direktur Departemen Pengajaran juga berhasil memasukkan bahasa Belanda ke dalam mata pelajaran wajib di sekolah rakyat dan sekolah pendidikan guru pada 1900.

Akhirnya, persaingan bahasa ini dimenangkan oleh bahasa Melayu. Kemudian di Kongres Pemuda I tahun 1926, bahasa Melayu menjadi wacana untuk dikembangkan sebagai bahasa dan sastra Indonesia. Lalu pada Kongres Pemuda II 1928, Sumpah Pemuda mengikrakan bahwa bahasa Indonesia merupakan bahasa persatuan Indonesia.
Bahasa Inggris pertama kali digunakan pada awal abad pertengahan Inggris yang pada awalnya adalah bahasa Jerman bagian barat. Bahasa Inggris muncul di kerajaan Anglo-Saxon dari Inggris yang saat ini berada di Skotlandia bagian tenggara. Berdasarkan pengaruh besar dari Inggris sejak abad ke-17 hingga pertengahan abad ke-dua puluh, melalui Imperium Inggris, bahasa Inggris telah tersebar luas di seluruh belahan dunia. Lalu, salah satu momentum terbesar -setelah kerajaan Inggris menguasai dunia- adalah ketika Amerika Serikat mendominasi media dan teknologi.

Istilah Old English pertama kali muncul di bagian pantai utara Britania Raya oleh imigran Jermanik (AngloSaxons) pada abad ke-5. Kata English sendiri, adalah bentuk modern dari englisc, sama dengan nama yang digunakan pada kata Anglesdan Saxons. Bahasa Inggris juga berada dibawah pengaruh bahasa the Old Norse oleh bangsa Viking pada abad ke-9 dan 10. Pada abad ke-11, invasi dan okupasi Inggris yang tergabung dalam tentara Norman, Breton dan Perancis yang dipimpin oleh William II dari Normandy, pada akhirnya memunculkan kosakata dan ejaan yang banyak dipinjam dari bahasa Norman Perancis. Hal ini berubah menjadi istilah Middle English yang mana memiliki 
pergeseran pada huruf vokal. Bahasa Inggris modern (Modern English) mulai muncul pada abad ke-15. Aktivitas simbolik sastra sebagai produk kultural bukan hanya memantulkan perspektif sosiologi tetapi juga memantulkan perspektif historiografi yang melahirkan kajian sastra poskolonial.

\section{METODE PENELITIAN}

Artikel ini merupakan hasil studi deskriptif (descriptive studies) yang menganalisis data berdasarkan fakta yang terjadi, kemudian mendeskripsikan secara sistematis, akurat, dan faktual mengenai objek yang dibahas dengan menggunakan teknik observasi, identifikasi, dan investigasi dalam penyelidikan, serta peninjauan terhadap rumusan masalah yaitu peran bahasa Indonesia dan bahassa Inggris sebagai penghela ilmu pengetahuan di era globalisasi .

\section{HASIL DAN PEMBAHASAN}

a. Bagaimana peran Bahasa Indonesia di era global

Bahasa yang semakin global dipakai oleh semua bangsa di dunia ialah bahasa Inggris, yang pemakainya lebih dari satu miliar. Akan tetapi, sama hanya denga bidang-bidang kehidupan lain, sebagaimana dikemukakan oleh Naisbii (1991) dalam bukunya Global Paradox, akan terjadi paradoks-paradoks dalam berbagai komponen kehidupan termasuk Bahasa pribumi dan Bahasa Inggris misalnya, walaupun pemakainya semakin besar sebagai bahasa keduanya masyarakat suatu negara akan semakin kuat juga memempertahankan bahasa ibunya.

Di Islandia, sebuah negara kecil di Eropa, yang jumlah penduduknya sekitar 250.000 orang, walaupun mereka dalam berkomunikasi sehari-hari menggunakan bahasa Inggris seabagai bahasa kedua, negara ini masih mempertahankan kemurnian bahasa pertamanya dari pengaruh bahasa Inggris. Di Kubekistan (Guebec), yang salama ini peraturan di negara bagian ini mewajibkan penggunaan bahasa Perancis untuk semua papan nama, sekarang diganti dengan bahasa sendiri. Demikian juga negara-negara pecahan Rusia seperti Ukraina, Lithuania, Estonia (yang memisahkan diri dari Rusia) telah menggantikan semua papan nama di negara tersebut yang selama itu menggunakan bahasa Rusia.

Bagaimana halnya dengan di Indonesia? Di Indonesia, fenomena yang sama pernah dilakukan dengan pengeluaran Surat Menteri Dalam Negeri kepada gubernur, bupati, dan walikota seluruh Indonesia Nomor 1021/SJ tanggal 16 Maret 1995 tentang Penertiban Penggunaan Bahasa Asing. Surat itu berisi instruksi agar papan-papan nama dunia usaha dan 
perdagangan di seluruh Indonesia yang menggunakan bahasa asing agar diubah menjadi bahasa Indonesia. Ketika awal pemberlakukan peraturan tersebut, tampak gencar dan bersemangat usaha yang dilakukan oleh pemerintah daerah di seluruh Indonesia. Pemda DKI Jakarta, misalnya, bekerja sama dengan Pusat Pembinaan dan Pengembangan Bahasa mengadakan teguran-teguran lisan dan tertulis, bahkan turun ke lapangan mendatangi perusahaan-perusahaan yang papan namanya menggunakan bahasa Inggris atau mencampuradukkan bahasa Inggris dan bahasa Indonesia dengan struktur bahasa Inggris. Misalnya, sebelumnya terpampang "Pondok Indah Mall”, "Ciputra Mall”, "Lippo Bank", "Mestika Bank", dan lain-lain, sekarang diubah menjadi "Mal Pondok Indah", "Mal Ciputra”, "Bank Lippa”, "Bank Mestika”.

\section{b. Bagaimana peran Bahasa Inggris di era global}

Bahasa Inggris sekarang bukan lagi hal yang sangat tidak biasa, tapi bahasa Inggris telah menjadi norma terutama di era globalisasi. Mampu berbicara dengan baik dan lancar bahasa Inggris tidak lagi menjadi nilai tambah, namun sudah menjadi tuntutan atau kebutuhan bagi setiap orang di era globalisasi saat ini. Ini karena pengaruh bahasa Inggris di hampir semua aspek dalam kehidupan.
Bahasa Inggris tidak hanya sebagai persyaratan akademis untuk penguasaan terbatas dalam aspek pengetahuan bahasa, tapi juga sebagai bahasa sains dan teknologi. Artinya bahasa Inggris digunakan untuk berkomunikasi dan diekstrak dalam sains dan teknologi. Sepertinya sebagian besar menggunakan bahasa Inggris, dan bahkan beragam dokumen dan pedoman teknis untuk penggunaan dan peningkatan perangkat yang bisa berbahasa Inggris. Menurut penelitian yang telah dicatat oleh Maurais dan Morris (2003), bidang sains dan teknologi juga mengandalkan bahasa Inggris. Dari satu miliar dokumen di situs web pada tahun 1999, sebesar 86,5\% digunakan dalam bahasa Inggris.

Bahasa Inggris juga digunakan untuk bekerja sama dalam dunia bisnis dengan pengusaha dari berbagai negara. Kesempatan kerja bagi seseorang yang menguasai bahasa Inggris terbuka lebar untuk menyambut kerja sama di perusahaan atau organisasi swasta atau instansi pemerintah, juga bisa mendapatkan posisi yang baik di perusahaan atau institusi tersebut. Hal ini mempersulit seseorang untuk mendapatkan pekerjaan yang lumayan tanpa keterampilan berbahasa Inggris. Dalam dunia bisnis yang semakin global, sejumlah perusahaan lokal termasuk perusahaan Indonesia telah memasuki 
dunia perdagangan dan menggunakan bahasa Inggris sebagai alat komunikasi utama, dan pada puncak perusahaan internasional yang memasuki perdagangan lokal karena penggunaan bahasa Inggris bahasa bisnis yang semakin dirasakan sebagai kebutuhan.

Bahasa Inggris akan menjadi lingua franca internasional setidaknya selama lima puluh tahun ke depan dan tidak ada bahasa tunggal yang menempati posisi monopoli pada abad kedua puluh (Graddol, 1997). Sebagai lingua franca internasional, bahasa Inggris tidak hanya disebut media komunikasi global, namun juga memainkan peran yang lebih penting dalam pendidikan, bisnis, diplomasi, teknologi, perdagangan, industri, perbankan, komputasi, kedokteran, penerbangan, teknik, budaya, sosial. instruksi, bahkan dalam semua aspek kehidupan.

Melihat kenyataan, kemampuan bahasa Inggris akan menjadi faktor penyumbang kesuksesan dalam bidang akademik dan pekerjaan. Oleh karena itu, di era globalisasi ini penting untuk belajar bahasa Inggris atau bahasa asing lainnya. Kebanyakan orang percaya bahwa era globalisasi sangat penting untuk menguasai setidaknya bahasa Inggris atau bahasa asing lainnya. Klaim lain bahwa jika tanpa penguasaan bahasa Inggris itu baik, sebuah negara tidak akan maju.
Dalam mempelajari bahasa Indonesia penutur asing memiliki tujuan masing-masing. Di dalam bukunya, bahwa ada banyak tujuan saat mereka belajar bahasa Indonesia. Tujuan itu antara lain untuk mempelajari budaya Indonesia.

Pemakaian bahasa bagi penutur asing dalam mempelajari bahasa Indonesia juga dipengaruhi oleh bahasa daerah. Hal ini dikarenakan dalam pergaulan seharihari, mereka berinteraksi dengan masyarakat sekitar.

\section{c. Bagaimana}

menyikapi

\section{keberadaan bahasa Indonesia dan bahasa Inggris di Indonesia}

Persaingan global semakin membuat setiap manusia di muka bumi ini berlomba - lomba untuk menjadi yang lebih baik. setiap manusia harus bisa menjadi mobile decession maker. Tidak hanya itu, waktu yang menjadi pemakan zaman nomor satu di dunia pun memaksa manusia untuk bisa thing outside the box.

Zaman sekarang, hanya bisa menggunakan satu bahasa saja sangatlah sulit untuk bisa masuk dalam global competition. Apalagi posisi negara kita yaitu sebagai negara berkembang yang masih memerlukan bantuan dan kontribusi dari negara lain khususnya negara maju. Dengan apakah agar kontribusi itu bisa 
diterima ? apalagi kalaubukan "bahasa" . Setiap individu setidaknya bisa menggunakan bahasa asing atau bahasa internasional. Kita tahu bahwa bahasa internasional Bahasa Inggris, untuk bisa berinteraksi dan berkomunikasi dengan orang dari negara lain, orang tersebut pasti menggunakan bahasa asing. Tidak terkecuali orang indonesia. Bahasa inggris, dimana merupakan bahasa asing di negara indonesia mempunyai peranan besar bagi indonesia itu sendiri. Pengaruh yang diberi pun beraneka ragam, ada yang memberikan pengaruh positif dan tidak jarang juga ada yang meberikan pengaruh negatif.

Dengan keberadaan bahasa asing sebagai bahasa internasional, pendidikan indonesia mulai dari taman bermain sampai dengan universitas memiliki kurikulum dan pelajaran tentang bahasa asing. Ini dilakukan agar sumber daya manusia indonesia dapat ikut andil dalam globalisasi dunia. Pengaruh yang cukup positif bukan ?

Pengaruh negatif dari bahasa asing itu sendiri ada. Belakangan ini, pengaruh negatif dari bahasa asing tersebut sudah terlihat. Cara pemakaian bahasa belakang ini yang sedang populer di semua kalangan adalah penggunaan bahasa campur aduk. Bahasa indonesia dikombinasikan dengan bahasa asing. Banyak generasi bangsa sekarang yang merasa lebih percaya diri dan gaul jika menggunakan bahasa campur aduk tersebut. Ini jelas mengurangi kekaedahan dan keabsahan akan bahasa indonesia yang menjadi bahasa persatuan itu sendiri.

Sejarah juga mencatat, bahwa presiden pertama republik indonesia, Soekarno pernah menggunakan tiga bahasa sekaligus dalam pidatonya. Dalam pidatonya tersebut, beliau menggunakan bahasa Indonesia, yang dicampuradukan dengan bahasa Sunda dan bahasa Belanda. Tidak hanya soekarno, aktivis nasional Soe Hok Gie, dalam bukunya catatan demostran, biasa mencampur bahasa Indonesia dengan bahasa Inggris. Itu pun berlangsung pada buku - buku lain sampai sekarang.

Jadi, ada dua pengaruh bahasa asing terhadap bahasa Indonesia itu sendiri, yaitu pengaruh positif dan pengaruh negatif. Pengaruh negatif itu sendiri terlihat pada generasi bangsa yang tidak lagi memperdulikan keabsahan bahasa indonesia.

\section{SIMPULAN}

Bahasa adalah perangkat komunikasi yang paling krusial, dan sekarang bahasa Inggris telah mendominasi semua aspek dalam hal komunikasi. Hampir semua perangkat elektronik menggunakan bahasa Inggris. Sebagian besar negara di Asia juga menggunakan bahasa Inggris sebagai 
media pengajaran dan menjadikan bahasa Inggris sebagai bahasa kedua setelah bahasa nasional mereka. Maka dari itu diperlukan sebuah kesadaran dari masyarakat, terutama masyarakat Indonesia sebagai pengguna bahasa Indonesia, dalam menggunakan bahasa Indonesia. Masyarakat harus lebih bijak dalam memilah-milah bahasa baik dan buruk yang mereka dengar di internet ataupun media lainnya, sehingga mereka dapat membatasi penggunaan bahasa alay yang berlebihan.

\section{DAFTAR PUSTAKA}

Muslich, Masnur. (2010). Bahasa Indonesia pada Era Globalisasi: Kedudukan, Fungsi, Pembinaan, dan Pengembangan. Jakarta: Bumi Aksara.

Panggabean, H. (2015). Problematic Approach to English Learning and Teaching: A Case in Indonesia. English Language Teaching. Canada: Canadian Center of Science and Education.

Indrawati, Sri. (2008). Penggunaan Bahasa Indonesia pada Informasi Layanan Umum dan Layanan Niaga, Sudah Benarkah?. Inderalaya

Abidin, Yunus. (2013). Kemampuan Menulis dan Berbicara Akademik. Bandung : Rizqi Press.

Nurudin. (2007). Pengantar Komunikasi Massa. Jakarta : Raja Grafindo Persada.
Sayoga. (2001). Pengaruh Bahasa Inggris pada Pembentukan Kosa-Kata Baru Berbahasa Indonesia, Bandung: Angkasa.

Samuel, J. (2008). Kasus Ajaib Bahasa Indonesia: Pemodernan Kosakata dan Politik Peristilahan. Jakarta: Pusat Bahasa. Prastika, Wayan. (2012). Pengaruh Bahasa Asing terhadap Bahasa Indonesia dan Bahasa Daerah: Peluang atau Ancaman?. Jurnal Kajian Bali, 02, 141-164.

Daimun . (2013). Pembelajaran Bahasa Indonesia pada Era Globalisasi. Jurnal Bahasa dan Seni, 14, 30-42

Murti, Sri. (2015). Eksistensi Penggunaan Bahasa Indonesia di Era Globalisasi. Prosiding Seminar Nasional Bulan Bahasa, 177-184

Nurhaidah, \& Musa, Insya. (2015). Dampak Pengarung Globalisasi Bagi Kehidupan Bangsa Indonesia. Jurnal Pesona Dasar, 03, 1-14

Assapari, Mugni. (2014). Eksistensi Bahasa Indonesia Sebagai Bahasa Nasional dan Perkembanganya di Era Globalisai. Jurnal Prasi, 09, 29-37

Marsudi, \& Zahrok, Siti. (2015). Kesetiaan Berbahasa Indonesia Dipertanyakan di Era Globalisasi. Jurnal Sosial Humaniora, 09, 95-105 
Saddhono, K. (2012). Kajian

Sosiolinguistik pemakasian Bahasa

Mahasiswa Asing Dalam Pembelajaran

Bahasa Indonesia Untuk Penutur Asing di

Universitas Sebelas Maret. Kajian

Linguistik dan Sastra. 24, 176-186

Yahya, M., Andayani., \& Saddhono, K. (2018). Studi Kesalahan Kalimat Dalam Karangan Pelajar Bahasa Indonesia Untuk Penutur Asing. DIALEKTIKA: jurnal bahasa, sastra, dan pendidikan bahasa dan sastra Indonesia.

Saddhono, K. (2017). Membangun Kearifan Lokal Melalui Karya Sastra dan Budaya Daerah [Jawa]. Prosding Seminar Nasional Bahasa dan Budaya 2017 